\title{
NOTES
}

\section{JOINDER AND IMPLEADER PRACTICE IN LIMITATION PROCEEDINGS: AN EXPANDED CONCOURSE FOR ADMIRALTY LITIGANTS*}

FEDERAL limitation of liability statutes ${ }^{1}$ and Admiralty Rule $51^{2}$ permit a shipowner, who may be liable in admiralty actions involving his ship, to restrict claims against him. The limitation on liability allowed is the combined value of the ship and freight earned at the end of the voyage. ${ }^{3}$ Total recovery

*British Transp. Comm'n v. United States, 230 F.2d 139 (4th Cir.), cert. granted, 25 U.S.L. WeEK 3104 (U.S. Oct. 8, 1956) (No. 247).

1. Rev. StAT. $\$ 4283$ (1875), as amended, 46 U.S.C. $\$ 183-89$ (1952).

"The liability of the owner of any vessel, whether American or foreign, for any embezzlement, loss, or destruction by any person of any property, goods, or merchandise shipped or put on board of such vessel, or for any loss, damage or injury by collision ... incurred, without the privity or knowledge of such owner ... shall not ... exceed the amount or value of the interest of such owner in such vessel, and her freight then pending."

Id. at $\$ 183(\mathrm{a})$.

2. Adairalty Rule 51 reads:

"Limitation of liability"-how clained.

"The owner or owners of any vessel who shall desire to claim the benefit of limitation of liability ... may file a petition in the proper District Court of the United States.... Such petition ... shall ... state facts showing ... the voyage on which the demands sought to be limited arose, ... the amount of all demands ... and the amount of any freight recovered or recoverable. ...

"....

"Upon the filing of ... [an] interim stipulation, or upon determination of value by appraisal ... . or upon compliance with a surrender order . . . the court shall issue a monition against all persons asserting claims in respect to which the petitioner seeks limitation.

"... The said court shall also, on the application of the petitioner, make an order to restrain the further prosecution of all and any suit or suits against the petitioner and/or said vessel in respect to any claim or claims subject to limitation in the proceeding."

See RuLES $52-55$ for other aspects of the proceeding.

The Supreme Court has authority to promulgate rules for admiralty practice. 62 STAT. 961 (1948), as amended, 28 U.S.C. § 2073 (1952). See ADMrRalty RULE 44, allowing district courts to regulate their practice in situations not provided for by the general rules.

3. Rev. Stat. $\$ 4283$ (1875), as amended, 46 U.S.C. $\S 183$ (1952).

It was not clear in the original statute that value was to be calculated at the end of the voyage or after collision. The Supreme Court held that this was to be the rule in The City of Norwich, 118 U.S. 468 (1886).

Provisions making a minimum of $\$ 60$ per ton of the vessel's tonnage available for wrongful death and bodily injury claims were added in 1935-36. 49 STAT. 960 (1935), 49 
is restricted to protect shipowners from the heavy liabilities which may be incurred in a single accident at sea, and thus to encourage maritime investment.4 Upon petition by a shipowner alleging that claims against him will be greater than the value of the vessel and upon surrender of the vessel or its value into court, a monition issues to all persons who may have claims. ${ }^{5}$ Because claimants who do not enter the limitation proceeding may be barred from prosecuting their claims in any other manner, ${ }^{6}$ limitation offers the owner the advantage of bringing all suits against him into a single trial. ${ }^{7}$ Though his ship be at fault, if the shipowner establishes his right to limit, ${ }^{8}$ the limitation fund represented by the ship or its value will be prorated among the claimants. ${ }^{9}$

STAT. 1479 (1936), 46 U.S.C. $\$ 183$ (1952). See Hearings before House Committee on Merchant Marine and Fisheries on H.R. 4550, 74th Cong., 1st Sess., pt. 2, at 5-14 (1935).

4. Cong. Globe, 31st Cong., 2d Sess. 713-17 (1851). Since enactment, the basic purposes of the statutes have not been debated in Congress, although modifications were made in 1935-36. See note 3 supra. But judicial statements of purpose abound. See, c.g., Norwich \& N.Y. Transp. Co. v. Wright, 80 U.S. (13 Wall.) 104 (1871) (first general judicial discussion of limitation) ; Maryland Cas. Co. v. Cushing, 347 U.S. 409, 413 (1954) ; Flink v. Paladini (The Henrietta), 279 U.S. 59, 62 (1929) ; Providence \& N.Y. S.S. Co. v. Hill Co., 109 U.S. 578, 588 (1883).

5. Admiralty Rule 51.

6. Rev. Stat. $\$ 4285$ (1875), as amended, 46 U.S.C. $\$ 185$ (1952). In some circumstances, however, a claimant's right to seek his remedy in the state courts is preserved. See Langnes v. Green, 282 U.S. 531 (1931) ; Ex parte Green, 286 U.S. 437 (1932); Robrwson, ADMIRALTY \$ 118 (1939).

7. The consolidated action resulting from limitation proceedings is referred to as a "concourse." Whether the concourse is a necessary part of the "Congressional scheme" in the limitation statutes is frequently argued. See, e.g., Maryland Cas. Co. v. Cushing, 347 U.S. 409 (1954). Four members of the Court believed a Louisiana statute allowing direct action against insurance companies conflicted with the concourse because it permitted an independent suit while a limitation action was in progress. Four justices dissented. The supporters of the concourse resolved the impasse by adopting the solution of Mr. Justice Clark, who believed congressional intent to be inconclusive, and voting to remand the "direct action" case pending determination of the limitation proceeding. See Note, 68 HARv. L. REv. 157 (1954).

The Second Circuit has held that if damages are reduced by stipulation below the amount in the limitation fund, the proceeding will not be used to assure a concourse and to deny claimants a jury trial in another forum. Petition of the Texas Co., The Washington, 213 F.2d 479 (2d Cir.), cert. denied, 348 U.S. 829 (1954) ; cf. Petition of the Trinidad Corp., The Fort Mercer, 229 F.2d 423 (2d Cir. 1955) (if stipulations are vulnerable to attack, claims must be reduced substantially below limitation fund before court should relax: concourse).

8. The right to limit is dependent upon a finding that the owner was not personally negligent in regard to the cause of the loss. See note 1 supra; see, e.g., The Malcolm Baxter, Jr., 277 U.S. 323, 331 (1928) ; Lord v. Goodall S.S. Co., 15 Fed. Cas. 884, No. 8506 (C.C. Cal. 1877), aff'd, 102 U.S. 541 (1880).

9. Admiralty Rule 52 declares that the distribution will be pro rata, "subject to all provisions of law thereto. ..." Such a situation arises when the value of the ship will furnish less than $\$ 60$ per ton to death and-bodily injury claimants, in which case they take priority over other claimants. 49 STAT. 960 (1935), 46 U.S.C. $\$ 183$ (b) (1952). See also 3 Benedict, Admiralty $\$ 530$ (6th ed. 1940) (hereinafter cited as Benedict). 
Initiated by a party who would normally be defending a suit, and often involving numerous claimants with conflicting interests, limitation actions have presented difficult problems of admiralty procedure. ${ }^{10}$ One of these problems is whether liberal joinder practice should be allowed in limitation proceedings to bring into one action other parties whose fault may have contributed to the underlying dispute. ${ }^{11}$ Admiralty courts generally deny petitions by the limiting shipowner or claimants entering the proceedings to bring in third parties or other claimants whose liability may be demonstrated during trial. ${ }^{12}$ The re-

10. See, e.g., Langnes v. Green, 282 U.S. 531 (1931) ; Ex parte Green, 286 U.S. 437 (1932) (limitation petitioner may not deprive sole claimant of right to forum; state court may apply federal statute with admiralty court retaining watchdog jurisdiction); In re Futnam (The Alcyone), 55 F.2d 73 (2d Cir.), cert. denied, 286 U.S. 558 (1932) (same result although limitation begun before claimant brought state action); Petition of the Texas Co., The Washington, 213 F.2d 479 (2d. Cir.), cert. denied, 348 U.S. 829 (1954) (concourse relaxed if damages sought are less than limitation fund).

For other areas of difficulty, compare The Titanic, 233 U.S. 718 (1914) (limitation affects remedy rather than right and is to be governed by law of the forum), with Black Diamond S.S. Lines v. Robert Stewart \& Sons, Ltd., 336 U.S. 386 (1949) (Belgian limit upon recovery may be applied in United States); see Just v. Chambers, 312 U.S. 383 (1941.) (where limitation denied shipowner, Florida law may be applied in admiralty, permitting claimants' cause of action to survive death of limiting party) ; The Eastland, 78 F.2d 984 (7th Cir.), cert. denied sub nom. Bishop v. St. Joseph-Chicago S.S. Co., 297 U.S. 703 (1935) (limitation being a special creation of statute and rule, no right to jury trial exists).

11. Impleader is permitted by Adarralty Rule 56 which reads:

"In any suit, whether in rem or in personam, the claimant or respondent (as the case may be) shall be entitled to bring in any other vessel or person (individual or corporation) who may be partly or wholly liable either to the libellant or to such claimant or respondent by way of remedy over, contribution or otherwise, growing out of the same matter...."

Under RuLe 56, only a defending party-"claimant" in an action in rem and "respondent" in an in personam suit-may implead. Since a limitation petitioner would ordinarily be a party defendant, he would fit within the meaning, if not the precise letter of the rule.

A claimant in a limitation proceeding is not a "claimant" as understood in RuLe 56; he could not, therefore, implead. Note, 2 STAN. L. REv. 211, 215 (1949). Nor is there any express joinder rule in admiralty akin to FED. R. CIV. P. 20(a). However, admiralty courts, permitting plaintiffs to sue several defendants or amend their libels freely to bring in new parties, have achieved the same result in practice. 2 BENEDICT $\$ \S 252,349,360$. Thus a limitation claimant could invoke the authority of admiralty courts to mold procedure to the needs of litigants. Hartford Acc. \& Indemnity Co. v. Southern Pac. Co., 273 U.S. 207, 217 (1927); The St. Lawrence, 66 U.S. (1 Black) 522, 528 (1861).

As used in this Note, "impleader" will refer to petitions by limiting shipowners, "joinder" to petitions by claimants in limitation proceedings. Occasionally joinder will be used more broadly to include both situations.

12. Department of Highways v. Jahncke Serv. Corp., 174 F.2d 894 (5th Cir. 1949) (claimant joining third party); New Jersey Barging Corp. v. T.A.D. Jones \& Co., 135 F. Supp. 97 (S.D.N.Y. 1955) (petitioner impleading claimant) ; Petition of Texas Co., 81 F. Supp. 758 (S.D.N.Y. 1948) (petitioner impleading claimant) ; Poling Bros. No. 5-Tom Wogan, 1937 Am. Mar. Cas. 1513 (E.D.N.Y.) (petitioner impleading third party) ; cf. The Steel Inventor, 1925 Am. Mar. Cas. 226 (E.D.N.Y.) (cross-libel prohibited in limitation action). But see The Clio-The Springhill, 1948 Am. Mar. Cas. 75 (S.D.N.Y.) 
luctance to expand the scope of limitation proceedings is based on a characterization of the action as a purely defensive statutory device the sole purpose of which is to enable the shipowner to restrict his liability. ${ }^{13}$ This attitude expresses itself in a variety of situations. Thus a limiting party has been refused impleader on the ground that his impleading petition sought to shift the focus of the proceeding from his liability to that of others. ${ }^{14}$ It has also been suggested that allowing impleader by a limiting owner or joinder by a claimant might compel the party brought into the action to litigate his liability in the limitation forum rather than in the one normally available to him. ${ }^{15}$ And in Department of Highways v. Jahncke Service Corp..$^{16}$ the Fifth Circuit, confronted with a claimant's petition to join a third party, simply declared that limitation constituted a distinct form of action to which the usually broad admiralty impleader rule was inapplicable. ${ }^{17}$

Recently, however, in British Transport Commission $v$. United States ${ }^{18}$ the Fourth Circuit reversed a district court and permitted joinder of one claimant by others in a limitation proceeding. After a collision between the Commission's DUKE of YORK and the United States transport HAITI VICroRx in the North Sea, the United States petitioned for limitation. The Commission entered as a claimant seeking damages. Answering the Commission's claim, the United States alleged that the DUKE's negligence alone had caused the collision. Death, personal injury and baggage claimants also entered the proceeding, petitioning to join the Commission in addition to seeking recovery from the United States. ${ }^{19}$ Following the orthodox view, the district court denied the petition. The court stated that to bring in the Commission and determine its liability in an American jurisdiction would be unfair when the Commission was compelled to enter the action to prosecute its claim at all. ${ }^{20}$ At trial the HaITI

(petitioner allowed to implead claimant); The City of Boston, 82 Fed. 171 (D. Mass. 1909) (claimants allowed to join third party).

13. See Department of Highways v. Jahncke Serv. Corp., 174 F.2d 894 (5th Cir. 1949) ; Algoma Cent. \& H.B. Ry. v. Great Lakes Transit Corp., 86 F.2d 708 (2d Cir. 1936); 3 BENEDICT, ADMIRALTY $\$ 479$ (6th ed. 1940); note 31 infra.

14. See New Jersey Barging Corp. v. T.A.D. Jones \& Co., 135 F. Supp. 97 (S.D.N.Y. 1955).

15. Ibid. See unreported opinion of district court, quoted in part in British Transp. Comm'n v. United States, 230 F.2d 139, 143 (4th Cir.).

16. 174 F.2d 894 (5th Cir. 1949).

17. Actually, the claimant sought to bring in the third party by way of impleader. The court did not discuss the language of RuLE 56 which clearly grants the right of impleader only to defending parties. See note 11 supra. The Fifth Circuit predicated refusal of "impleader" on the nature of the limitation proceeding and on the "origin, nature and extension" of RULE 56 without greater specificity. 174 F.2d at 895 .

18. 230 F.2d 139 (4th Cir.), cert. granted, 25 U.S.L. WeEK 3104 (U.S. Oct. 8, 1956) (No. 247).

19. Suits against the United States are permitted by the Suits in Admiralty Act, 41 STAT. 525 (1920), 46 U.S.C. $\$ \$ 741-52$ (1952).

20. Unreported memorandum quoted in part in Fourth Circuit's decision. $230 \mathrm{~F} .2 \mathrm{~d}$ at 143. 
was exonerated and the Duke found solely to blame for the collision, 21 a finding affirmed on appeal. The Fourth Circuit held, however, on appeal by the claimants, that the petition for joinder should have been allowed. ${ }^{22}$

In breaking with the traditional attitude toward joinder, the appellate court acted on three main considerations. It noted first that the DukE's negligence had been determined in the limitation action and that the question would be res judicata in later proceedings. ${ }^{23}$ Therefore, the court stated, only the question of each claimant's damages remained and this should have been determined in the district court. The court next invoked the admiralty-equity principle that once a tribunal has assumed jurisdiction in a matter, it would apply complete relief to all parties before it. ${ }^{24}$ The court buttressed its conclusion by appeal to policies underlying modern procedure: all rights relating to a single cause of action should be decided in one proceeding and parties who submit themselves to a court's jurisdiction should be bound by its decision. ${ }^{25}$ These principles, the Fourth Circuit declared, dictated a full disposition in the limitation action of all claims arising from the collision. ${ }^{26}$

The Fourth Circuit's decision appears to be a commendable departure from previous admiralty practice denying joinder of parties in limitation proceedings. But since that practice is strongly supported in modern case law, the decision should be evaluated in terms of the history and purpose of limitation proceedings and the consequences a broad rule may produce. And the application of such a rule to the peculiar facts in British Transport requires special analysis.

21. Petition of the United States, The Haiti Victory, 131 F. Supp. 712 (E.D. Va. 1955). See Note, S Stan. L. Rev. 273 (1956).

22. The Fourth Circuit recognized that a literal reading of RuLe 56 would not allow a limitation claimant to implead. See note 11 supra. However it based its procedural result on the equitable nature of admiralty courts, using RULE 56 for guidance. 230 F.2d at 145.

23. Id. at 144. The court cited The Adah, 258 Fed. 377 (2d Cir. 1919), and Algoma Cent. \& H.B. Ry. v. Great Lakes Transit Corp., 86 F.2d 708 (2d. Cir. 1936). These cases held that the finding on negligence in a limitation proceeding was res judicata in United States courts. The Adah, supra, made no statement of the res judicata effect of the finding in courts of another nation. Algoma, supra, which like British Transport involved a forcign party, declared only that the finding would probably be res judicata abroad. This reservation in Algona reflects an awareness of a court's ultimate freedom to reject a foreign tribunal's decision on a matter between the parties. See Hilton v. Guyot, 159 U.S. 113 (1895). In international practice, however, a foreign court's decision will normally be accepted under the doctrine of reciprocity. See StuMreER, Conflict of Laws 130-33 (2d ed. 1951) ; Katzenbach, Confiicts on an Unruly Horse: Reciprocal Claims and Tolerances in Interstate and International Law, 65 YALE L.J. 1087, 1135 (1956).

24. 230 F.2d at 144 . The court rested on Hartford Acc. \& Indemnity Co. v. Southern Pac. Co., 273 U.S. 207 (1927) (admiralty court retained jurisdiction although shipowner failed to establish right to limit), and Just v. Chambers, 312 U.S. 383 (1941) (same).

25. 230 F.2d at 145. See Clark, Code Pleading $\$ 19$ (2d ed. 1947); note 49 infra.

26. The Second Circuit, citing British Transport as persuasive, recently reached a similar result by permitting a limiting shipowner to cross-libel three claimants. Convenience of practice was a compelling factor in the view of the court. Moore-McCormack Lines, Inc. v. McMahon, 235 F.2d 142 (2d Cir. 1956). 
The history of limitation practice does not disclose compelling reasons for viewing the action as a one-way defensive proceeding. Nothing in the original limitation statutes requires continued acceptance of this narrow approach underlying denial of joinder. ${ }^{27}$ In 1871, the Supreme Court traced the outlines of modern limitation proceedings, ${ }^{28}$ asserting that the action could be initiated by a shipowner. But the procedure was not mandatory $;^{29}$ limitation could be claimed as a partial defense in the usual admiralty suit or combined with a right of recovery by way of counter-claim. ${ }^{30}$ In fact, until the mid-thirties no admiralty decision found suggested that limitation was purely defensive. ${ }^{31}$ After 1935 Congress required a limiting party desiring the concourse to invoke the

27. 9 Stat. 635 (1851).

28. 80 U.S. (13 Wall.) xii-xiv (1872). Formulation of the procedure resulted from problems raised by Norwich \& N.Y. Transp. Co. v. Wright, 80 U.S. (13 Wall.) 104 (1871), in which limitation was invoked for the first time in a collision situation. The effect of the statute was mentioned only incidentally before 1871 . See, e.g., The Baltimore, 75 U.S. ( $S$ Wal1.) 377, 385 (1869) ; Moore v. Transp. Co., 65 U.S. (24 How.) 1 (1860).

29. Ex parte Slayton, 105 U.S. 451 (1881); The Scotland, 105 U.S. 24, 33-35 (1881); The Benefactor, 103 U.S. 239, 244 (1880). The H.F. Dimock, 52 Fed. 598, 599 (S.D.N.Y. 1892) illustrates this early flexibility, outlining four methods by which a shipowner could secure limitation. Paradoxically, the description of limitation as sui generis, used today as a reason for denying flexibility, see Department of Highways v. Jahncke Serv. Corp., 174 F.2d 894 (5th Cir. 1949), was originally a reason for allowing whatever procedures were necessary for convenient practice. The City of Norwich, 5 Fed. Cas. 782, No. 2762 (E.D. N.Y. 1873), aff'd by $2 d$ Cir. (unreported), aff'd, 118 U.S. 468 (1886). See also The Adah, 258 Fed. 377 (2d Cir. 1919).

30. See The North Star, 106 U.S. 17 (1882); The Benefactor, 103 U.S. 239 (18s0); Gleason v. Duffy, 116 Fed. 298 (7th Cir. 1902); The Ethelstan, 246 Fed. 187 (S.D. Fla. 1917); In re Starin, 124 Fed. 101 (E.D.N.Y. 1903); The S.A. McCaulley, 99 Fed. 302 (E.D. Pa. 1899).

31. The idea appears to have originated in Algoma Cent. \& H.B. Ry. v. Great Lakes Transit Corp., 86 F.2d 708 (2d Cir. 1936). In Algoma a foreign claimant was prevented from instituting his own limitation proceeding in the United States under ADMrralty RuLE 54 after he had filed a claim in a domestic limitation action. The claimant desired the benefit of the American limitation statute, which was more favorable than his own nation's. The court held that a limitation proceeding was not itself a "suit" against an entering claimant within the meaning of RULE 54 but was designed to compel a concourse of claims. The holding is equivocal on the defensive nature of limitation procecdings, but together with a dictum declaring that the limiting shipowner "cannot recover a dollar" through the action, it has been relied upon to restrict limitation. Se'e Department of Highways v. Jahncke Serv. Corp., 174 F.2d 894 (5th Cir. 1949) ; New Jersey Barging Corp. v. T.A.D. Jones \& Co., 135 F. Supp. 97 (S.D.N.Y. 1955). These decisions have also extended to Rule 56, see note 11 supra, Algoma's refusal to regard the proceeding as a "suit," thus seizing upon another reason for disallowing impleader in a limitation action.

Furthermore, not until the sixth edition of BENEorct is limitation interpreted as a distinct form of action or as a defensive proceeding. In 2 BENEDICT $\$ 228$ (6th ed. 1940) limitation appears as an independent action and only in the third volume, with a sole citation to Algoma, supra, does the proceeding become "defensive." 3 id. \$ 479.

Possibly the defensive concept of limitation gains support by analogy to foreign limitation proceedings. But there an admission of fault is usually necessary to a commencement of the action, thus confining the procedure substantially to a mere apportionment of the fund. Foreign limitation processes are collected, id. at $\$ 543$. 
statute by petition within six months after notice of a claim against him. ${ }^{\mathbf{3 2}}$ Forcing the shipowner to initiate the action and prescribing the time in which the proceeding could be instituted, the statute precludes limitation as a partial defense in an ordinary action. However, the statute need not qualify any right of recovery which the shipowner may previously have had; it restricts the way in which limitation can be used defensively, but it does not necessarily make a limitation proceeding exclusively defensive. Actually, courts have labelled limitation a one-way defensive action only recently, with little citation of authority. At best these decisions supply only scant historical evidence that the action was designed to be restrictive.

The inconclusive history of limitation as a defensive action contrasts with the efficiency and convenience liberal joinder rules provide elsewhere in admiralty and civil actions. ${ }^{33}$ Through impleader and other devices admiralty courts have achieved skill in handling the many-cornered controversies which often arise in maritime cases. ${ }^{34}$ Effective operation of impleader in admiralty was a significant reason for its incorporation into the Federal Rules of Civil Procedure. ${ }^{35}$ Without joinder, circuity and duplication of actions may cause a considerable waste of time and money for courts and parties. If third parties cannot be brought in, conflicting findings on fault and liability from the same set of facts heard in different cases by different tribunals could also result.

These dangers are illustrated by situations arising in limitation actions. Limitation proceedings may establish the fault of any number of parties, claimants or outsiders as well as the limiting shipowner. Thus a limiting party's best defense is to fix the blame elsewhere either in whole or in part. If, as in British Transport, a claimant is found entirely at fault, absent joinder neither the limiting party nor other claimants can recover on the basis of this finding without instituting another proceeding in which they must prove damages. ${ }^{36}$ The

32. 49 STAT. 1480 (1936), 46 U.S.C. $\$ 185$ (1952). A later case held that limitation may still be raised in answer to a libel. See The Chickie, 141 F.2d 80 (3d Cir. 1944); cf. The West Point, 83 F. Supp. 680 (E.D. Va. 1949) (if limitation raised in answer, shipowner may be liable up to the value of the vessel on each claim); Note, 28 TExAs L. REv. 433 (1949). But see Cantwell v. Meade, 120 F. Supp. 406 (E.D.N.Y. 1954). Even if The Chickie, supra, is generally followed, limitation as a partial defense to a libel does not help a shipowner faced with numerous claims, for he loses the benefit of the concourse.

33. 2 Benedict 349-51. Clakk, Code Pleading $\$ 64$ (2d ed. 1947). An impressive number of cases litigated conveniently by use of impleader is collected in Note, 34 CorNeLL L.Q. 403 (1949). The Note points out that courts are reluctant to expand impleader, but the desirability of the practice is clearly shown and convincing methods of further application are suggested.

34. See, c.g., O. Maire, Inc. v. The Yaka, 79 F. Supp. 659 (S.D.N.Y. 1948) ; Lamborn $\&$ Co. v. Compania Maritima del Nervion, 19 F.2d 155 (S.D.N.Y. 1927); The Mauch Chunl, 139 Fed. 747 (S.D.N.Y. 1905), aff'd, 154 Fed. 182 (2d Cir.), cert. denied sub nom. Central R.R. v. Wren, 207 U.S. 586 (1907).

35. FED. R. Crv. P. 14. On the admiralty origin of the federal rule, see Note's of Advisory Committee on Rules, 28 U.S.C. following RuLE 14 (1952).

36. This was one of the reasons for granting joinder in British Transport. $230 \mathrm{~F} .2 \mathrm{~d}$ at 144 . 
situation is aggravated if an outside party is shown in the limitation action to be at fault. Here fault as well as damages must be demonstrated anew in the second proceeding, since no decision in the original limitation action could bind the outside party. If the limiting party and a third party are both found at fault in the limitation action, a second independent proceeding must again be instituted for the limiting party to compel the third party's contribution. ${ }^{37}$ In the last two examples conflicting results in different tribunals may occur; in all situations full settlement of claims is unobtainable in the limitation action alone. ${ }^{38}$ A device similar to joinder, consolidation of actions, has been employed to achieve full settlement. But while consolidation may have the same practical effect as joinder, its scope is more limited $;^{39}$ furthermore, it seems an empty formalism to require the initiation of an independent suit, ${ }^{40}$ thus subjecting both courts and parties to unnecessary inconvenience.

Nor would joinder of a party, whether domestic or foreign, cause hardship in most limitation actions. Domestic parties would suffer no loss of substantive

37. See Halcyon Lines v. Haenn Ship Ceiling \& Refitting Corp., 342 U.S. 282 (1952), restricting the right to contribution to collision cases; Note, 21 GEo. WASH. L. REv. 241 (1952).

38. In Petition of Texas Co., 81 F. Supp. 758, 762 (S.D.N.Y. 1948), the court suggests that full settlement may be achieved in a single proceeding when both a claimant and a limiting party are found at fault. In such a case, the court argued, the claimant-shipowner's claim would be allowed at half his damages. Apparently the court reached this result by applying to a limitation action the usual admiralty formula of equal division of damages. The Chattahoochee, 173 U.S. 540, 554 (1898). But, by viewing the limitation proceeding as a purely defensive action, the court eliminated the part of the rule allowing the other party, here the limiting shipowner, to recover half his damages. Against the half-claim granted the claimant-shipowner the court would permit the limiting party to set off, as contribution from a joint tortfeasor, see note 37 supra, one half the amount awarded the other claimants. The elimination of the limiting party's own damages seems a misapplication of the holding of The North Star, 106 U.S. 17 (1SS2) (even in limitation a balance of liability must be struck). In Texas Co., however, a finding that the limiting party was entirely at fault made application of any division-of-damage formula unnecessary. Under the defensive concept the formula, even if properly applied, may be inadequate to achieve full settlement of all claims, including the limiting party's, since an affirmative recovery is sometimes required to compensate the limiting party fully for the injury to his own ship under the equal damage rule. For this purpose a second suit would have to be brought.

39. Southern Pac. Co. v. United States, 72 F.2d 212 (2d Cir. 1934). Although commonly used, the practice is governed by no general admiralty rule. FED. R. Crv. P. 42(a) is the relevant civil rule. Consolidation is within the discretion of the court. It is limited to situations in which suits are pending in the same district. Barton v. Royal Rotterdam S.S. Co., 1952 Am. Mar. Cas. 1169 (S.D.N.Y.). The practice is useful where both ship owners are entitled to limit in the same district and many claims have been filed against each, since impleader can be used only by one limiting party to bring in another; but claimants in the second limitation action, who are clearly not liable, such as individual passengers, cannot be impleaded. Consolidation was desirable, therefore, in the recent Andrea Doria-Stockholm collision. N.Y. Times, Sept. 20, 1956, p. 26, col. 6.

40. The requirement of an independent suit has been suggested in, c.g., The Steel Inventor, 1925 Am. Mar. Cas. 226 (S.D.N.Y.). See also Note, 2 Stan. L. Rev. 211 (1949). 
rights, since admiralty claims filed against them anywhere in the United States would be governed by uniform federal law. ${ }^{41}$ Likewise, joinder of foreign parties would cause them no disadvantage in most cases since they could be sued in an independent action. Such parties would almost always be large shipowning companies whose activities in the United States readily subject them to American jurisdiction in the same manner as domestic parties. ${ }^{42}$ If subjected to American process in any suit, foreign shipowners may limit under the United States statute. ${ }^{43}$ Were this same right accorded a foreign party brought into a domestic limitation action, he would thus be assured the protection available in an independent suit. And whether brought in by a limiting party or a claimant, the third party is protected from being forced into a forum where he could not otherwise be sued, since the requirement of territorial jurisdiction limits service of process to the state in which the limitation action is brought. ${ }^{4}$

41. "[N]o state legislation is valid if it . . works material prejudice to the characteristic features of the general maritime law or interferes with the proper harmony and uniformity of that law in its international and interstate relations. ..." Southern Pac. Co. v. Jensen, 244 U.S. 205, 216 (1917). This decision left the states to their own procedure but imposed upon them a federal substantive admiralty law. The case has been somewhat modified but still stands. See Western Fuel Co. v. Garcia, 257 U.S. 233 (1921) (state law may operate where cause of action is "maritime but local"); Robinson, AdmIRalty $\$ 14$ (1939). See also Comment, 57 Y ALE L.J. 243, 245 (1947) and articles cited.

Of course, outside the limitation forum a right to jury trial may exist; but this right is not likely to be important to a limiting shipowner faced with negligence actions. See, c.g., Langnes v. Green, 282 U.S. 531 (1931); The Eastland, 78 F.2d 984 (7th Cir. 1935); Robinson, Admiralty $\$ 118$ (1939).

42. Admiralty Rule 2 governs suits in personam; Rule 10 governs suits in rem. For an example of a foreign shipowner made subject to United States process, see Kloeckner Reederei und Kohlenhandel v. A/S Hakedal (The Western Farmer), 210 F.2d 754 (2d Cir.), dismissed, 348 U.S. 801 (1954).

43. E.g., The Titanic, 233 U.S. 718 (1914); cf. Black Diamond S.S. Lines v. Robert Stewart \& Sons, Ltd., 336 U.S. 386 (1949), implying that Belgian limit upon liability may apply in the United States when tort occurred in Belgian waters; Note, 17 U. CHr. L. REv. 388 (1950). But see The Vestris, 53 F.2d 847 (S.D.N.Y. 1931) (wording of Wrongful Death on the High Seas Act, 41 STAт. 537 (1920), 46 U.S.C. $\$ \$ 761-68$ (1952), excludes foreigners from limiting in United States against wrongful death claims).

The foreign party probably would not be permitted to avoid a suit in the United States by limiting abroad. See Kloeckner Reederei und Kohlenhandel v. A/S Hakedal (The Western Farmer), supra note 42 (pending limitation proceeding in Great Britain not ground for dismissing suit in United States). Suggestions that foreign limitation actions be more widely honored have been made. See Maritime Law Association of the United States Docunent No. 393, Report on the Plenary Conference of the Conité Maritiare International HeLd AT MAdRID (Sept. 18-24, 1955), proposing an International Convention dealing with limitation of liability and giving the shipowner a wide choice of forum. The United States delegation voted against the Convention.

Even the denial of a foreign limitation forum is often not serious. In contrast to most foreign legislation, the United States limitation statutes do not require an admission of fault. See 3 BENEDICT $\$ 543$. On the other hand foreign statutes may contain a more desirable substantive limit on liability. See, e.g., Black Diamond S.S. Lines v. Robert Stewart \& Sons, Ltd., supra.

44. Although not specifically covered in AdsIRALty Rules, state-wide service of process has long been the rule in admiralty practice. See The Resolute, 14 F.2d 232 (E.D. 
The holding in British Transport permitting joinder of one claimant by others should be expanded to allow joinder of third parties who have not entered the limitation action but may be liable. An uninjured third party has no reason to enter the limitation proceeding; but a claimant should not be without power to compel the appearance of such a party, since otherwise the findings on fault may prevent his full recovery in this action. While the limiting party may have less valid reason than a claimant for demanding impleader of a third party, he should also be granted the right. A claimant is forced to enter the limitation action to preserve his remedy. ${ }^{45}$ As a result, however, his recovery may be limited and he will be forced to compete with others for his share of the limitation fund. A limiting party, on the other hand, gains the advantages of restricted liability and the concourse. It could be argued that for the shipowner these advantages of limitation are sufficient. But this view neglects the desirability of achieving full settlement of claims with least duplication of suits.

Although it seems clear, therefore, that joinder in limitation proceedings is normally desirable, the relationship of the parties in British Transport raises doubt whether the procedure should have been permitted. The Commission had not limited in England since there most of the claims against it were barred: the United States' suit by a bilateral agreement with Great Britain ${ }^{40}$ and most individual claims by ticket exoneration clauses. ${ }^{47}$ While the United States' claim was also barred in this country, impleader exposed the Commission to individual claims in an American forum, where exoneration clauses are held contrary to public policy. ${ }^{48}$ The Fourth Circuit's decision thus deprived the Commission of a significant substantive right. The court should have discussed the problems raised by the conflict of laws between the two jurisdictions,

N.Y. 1926). The admiralty usage is indistinguishable from the civil rule, FEn. R. Crv. P. 4(f). Patel Cotton Co. v. The Steel Traveler, 107 F. Supp. 191, 193 (S.D.N.Y. 1952).

Note, 34 CoRNELL L.Q. 403, 412 (1949) suggests that the utility of impleader in civil practice, FED. R. Crv. P. 14, might be enhanced by nation-wide service of process. The same arguments are even more compelling when applied to admiralty where the doctrine of Erie v. Tompkins, 304 U.S. 64 (1938) has no application. See note 41 supra.

45. Rev. Stat. \$ 4285 (1875), as amended, 46 U.S.C. $\$ 185$ (1952).

46. Brief for Appellee, p. 79, British Transp. Comm'n v. United States, 230 F.2d 139 (4th Cir.), cert. granted, 25 U.S.L. WeEK 3104 (U.S. Oct. S, 1956) (No. 247). The "Knock-for-Knock" agreement referred to, 56 Stat. 1780 (1942), provides that the United States and Great Britain will not prosecute maritime claims against each other and each other's agents. The Commission maintained, however, that it was not an agency of the British government, although subsidized by the government and operating nationalized private property, and thus was not barred from suit by the "Knock-for-Knock" agreement. Exhibit B, Certificate of British Chargé d'Affaires, Petition of the United States, Haiti Victory, 131 F. Supp. 712 (E.D. Va. 1955) (photostat on file in the Yale Law Library). For support of the Commission's view, see Tamlin v. Hannaford, [1949] 2 All E.R. 327 (C.A.); see also 12 Modern L. Rev. 496 (1949).

47. See, e.g., Adler v. Dickson, [1954] 2 Lloyd's List L.R. 267 (C.A.).

48. Oceanic Steam Nav. Co. v. Corcoran, 9 F.2d 724 (2d Cir. 1925); 49 Stat. 960, 46 U.S.C. $\S 183$ (b) (1952). See Note, 65 Yale L.J. 553, 560 (1956). 
for the loss of the ticket exoneration defense seems crucial in determining the propriety of joinder.

On balance, however, permitting joinder was justified in spite of the hardship it occasioned the Commission. In other areas of law, courts have settled all parties' rights even though objection was raised that some of them, otherwise immune from suit, had entered a proceeding only for the limited purpose of protecting their remedies. ${ }^{49}$ In these instances defenses similar to the Commission's were considered and rejected. Moreover, even under the uncommon facts of British Transport, only a party found at fault will be penalized by the joinder rule. Since international rules generally govern a collision on the high seas ${ }^{60}$ and the law of the place of the tort will govern elsewhere, ${ }^{51}$ the same law would be applied by any tribunal to determine fault.52 Accordingly no joined party can complain of being deprived of a more advantageous substantive law of fault available elsewhere. The choice consequently lies between the value placed on a full settlement of liability, on one hand, and the value accorded to a defense of immunity, which courts have increasingly rejected, on the other. Finally, foreign parties such as the Commission may avoid any finding at all on their negligence if they are willing to forego their claims by remaining out of the limitation action. Fully apprised of the applicable law and with clear linowledge of facts supporting charges of negligence against them, these parties can intelligently gauge the risk that they will be found liable if they enter the action.

49. United States v. The Thekla, 266 U.S. 328 (1924) (when United States takes pasition of private suitor counterclaims may be asserted against it); National City Bank v. China, 348 U.S. 356 (1955) (foreign sovereign also waives immunity from claim by entering). The court in British Transport confined itself to an analogy from receivership proceedings where affirmative recoveries have been secured against entering claimants. See Alexander v. Hillman, 296 U.S. 222 (1935). See Note, 65 YALE L.J. 694 (1956).

50. The Belgenland, 114 U.S. 355 (1885). The rules are given in 26 Stat. 320 (1890), as amended, 33 U.S.C. $\$ \$ 61-147$ (d) (1952). When ships of the same nation collide, the law of their flag will be applied in a foreign forum. The Scotland, 105 U.S. 24, 29 (1881). See Note, 31 Texas L. Rev. 889, S94-96 (1953).

51. The Mandu, 102 F.2d 459 (2d Cir. 1939). See Goodrich, Conflict of Laws $\$ 92$ (3d ed. 1949).

52. Ibid. 